INTERNATIONAL JOURNAL OF RESEARCHES IN BIOSCIENCES, AGRICULTURE AND TECHNOLOGY (C) VISHWASHANTI MULTIPURPOSE SOCIETY (Global Peace Multipurpose Society) R. No. MH-659/13(N) www.vmsindia.org

\title{
CHRONIC OBSTRUCTIVE PULMONARY DISEASES IN WOMEN IN RURAL AREA OF SANGLI DISTRICT, MAHARASHTRA, INDIA
}

\author{
P. M. Patil ${ }^{1}$ and R. G. Patil ${ }^{2}$ \\ ${ }^{1}$ Dr Patangrao Kadam Mahavidylaya, Sangli, Maharashtra, India \\ ${ }^{2}$ L.B.S. College, Satara, Maharashtra, India \\ patilpm16@gmail.com
}

\begin{abstract}
:
On a global scale the most important source of indoor air pollution is the use of solid fuels for domestic cooking. In developing country including India, majority of household depends on biomass fuel as the primary source of energy for cooking especially in rural areas. Use of biomass fuel, such as wood in poorly-ventilated kitchen, causes indoor air pollution. Incomplete combustion of unprocessed solid biomass fuel releases smoke which contains high volume and number of health damaging airborne pollutants including respirable particulate matter PM10 and , Carbon Monoxide(CO) and many other organic compounds .) Prolonged exposure to indoor air-borne pollutants causes adverse effect on lung function which causes COPD (Chronic Obstructive Pulmonary Disease). COPD is the inflammation and swelling of the lining of the airways that leads to narrowing and obstruction of the airways. The type of house, location of kitchen and type of fuel used play a significant role on women's health. In the present study 100 biomass fuel users and 100 LPG users women underwent spirometry. Out of 100 biomass fuel users 45 women were suffered from COPD i.e. FEV1\% < 80\% and FEV 1 / FVC\% $<80 \%$
\end{abstract}

Keywords: COPD, FEV1\% (Force Expiratory Volume / 1 second), Biomass Fuel Smoke.

\section{Introduction :}

On a global scale the most important source of Indoor air pollution is the use of solid fuels for domestic cooking (Smith K.R. 2004). In India $90 \%$ households use wood as the primary cooking fuel (IIPS). The most important factor in the life of average Indian housewife is the domestic cooking. The typical Indian household life revolves around the cooking area and Indian women spent much of the time there. The type of house, location of kitchen and type of fuel used play a significant role on women health. Incomplete combustion of unprocessed solid biomass fuel releases smoke which contains high volume and number of health damaging airborne pollutants including respirable particulate matter $\mathrm{PM}_{10}$ and $\mathrm{PM}_{25}$, Carbon Monoxide(CO), Nitrogen Oxide $\left(\mathrm{NO}_{2}\right)$ and Sulphur Oxide( $\left(\mathrm{SO}_{2}\right)$, Formaldehyde and many other organic compounds.(Bruce et al., 2000) Prolonged exposure to smoke causes' adverse effect on lung function which causes COPD (Chronic Obstructive Pulmonary Disease). COPD is the inflammation and swelling of the lining of the airways that leads to narrowing and obstruction of the airways. Shengming, et al. (2007) studied the association between Chronic Obstructive Pulmonary Disease (COPD) and the use of biomass fuels for cooking and heating in developing countries. In a hospital based case controlled study conducted by Rodolofetal, et al. (1996) in Bagota, Columbia to identify risk factors for obstructive airway disease in women found that wood smoke exposure was associated with development of COPD and may help to explain around $50 \%$ of all COPD cases.

\section{Material and Methods:}

Total 200 women were participated in this study. The biomass fuel users group was represented by 100 women from 2 villages i.e. Budhgaon and Wajegaon in Sangli district. Another group of LPG users was represented by 100 women from same villages of Sangli district. All women were 25 years of age or older. Biomass fuel users were from low socioeconomic status. All women were interviewed and information was collected about type of house, type of Kitchen, no. of years exposure to biomass smoke, no. of hrs/day exposed to smoke. Spirometry was performed in 100 biomass fuel users (subjects) and 100 LPG users (control). Force expiratory volume/1 second (FEV $1 \%)$ and ratio of force expiratory volume/1second / force vital capacity were recorded. Women having FEV $1 \%<80 \%$ and FEV1/ FVC\% < 80\% were considered as COPD. (Miller et al, 2005)

\section{Statistical analysis:}

$Z$ significance test was used. ' $Z$ ' value for control and subject was calculated, using formula

$$
C a l|z|=\left[\frac{\overline{x 1}-\overline{x 2}}{\sqrt{\frac{\sigma 1^{2}}{n_{1}}+\frac{\sigma 2^{2}}{n_{2}}}}\right]
$$

based on null hypothesis to show significant difference between control and subject.

$\mathrm{HO}: \mathrm{H} 1, \mathrm{HO} \rightarrow$ There is no significant difference in subject and control . $\mathrm{H} 1 \rightarrow$ There is significant difference between subject and control .

Cal $|Z|=>$ table $Z=1.96$ at $5 \%$ level of significance. 
$\therefore$ Reject $\mathrm{HO}$

Accept $\mathrm{H} 1$ $\therefore$ There is significance difference between FEV 1\% control and FEV1\% experimental.

\section{Observation:}

Table No. 1 Information Of Women Using LPG in Budhgaon and Wajegaon.

\begin{tabular}{|c|c|c|c|c|c|c|c|c|}
\hline \multirow{2}{*}{ SR. No } & $\begin{array}{c}\text { Name of } \\
\text { Village }\end{array}$ & $\begin{array}{c}\text { No. of } \\
\text { Tomen } \\
\text { Type of } \\
\text { Fuel }\end{array}$ & $\begin{array}{c}\text { No. of } \\
\text { women } \\
\text { House type }\end{array}$ & $\begin{array}{c}\text { No. of } \\
\text { women } \\
\text { Kitchen } \\
\text { type }\end{array}$ & \multicolumn{2}{|c|}{$\begin{array}{c}\text { No. of } \\
\text { women } \\
\text { Years of } \\
\text { Exposure }\end{array}$} & \multicolumn{2}{|c|}{$\begin{array}{c}\text { No. of women Hours } \\
\text { of Exposure }\end{array}$} \\
\cline { 2 - 8 } & LPG & Concrete & Indoor & $>15$ & $<15$ & $>4$ & $<4$ \\
\hline 1 & Budhgaon & 50 & 50 & 50 & 35 & 15 & 36 & 14 \\
\hline 2 & Wajegaon & 50 & 50 & 50 & 41 & 9 & 25 & 25 \\
\hline & Total & 100 & 100 & 100 & 76 & 24 & 71 & 29 \\
\hline & Mean & 50 & 50 & 50 & 38 & 12 & 30.5 & 19.5 \\
\hline
\end{tabular}

Table No. 2- Information Of Women Using Exposed To Biomass Smoke In Budhgaon and Wajegaon.

\begin{tabular}{|c|c|c|c|c|c|c|c|c|c|c|c|}
\hline \multirow{2}{*}{$\begin{array}{l}\text { Sr. } \\
\text { No. }\end{array}$} & \multirow{2}{*}{$\begin{array}{l}\text { Name of } \\
\text { Village }\end{array}$} & \multicolumn{2}{|c|}{$\begin{array}{l}\text { No. of women } \\
\text { Type of Fuel }\end{array}$} & \multicolumn{2}{|c|}{$\begin{array}{c}\text { No. of women House } \\
\text { type }\end{array}$} & \multicolumn{2}{|c|}{$\begin{array}{l}\text { No. of women } \\
\text { Kitchen type }\end{array}$} & \multicolumn{2}{|c|}{$\begin{array}{l}\text { No. of women } \\
\text { Years of } \\
\text { Exposure }\end{array}$} & \multicolumn{2}{|c|}{$\begin{array}{c}\text { No. of women } \\
\text { Hours of } \\
\text { Exposure }\end{array}$} \\
\hline & & Wood & $\begin{array}{c}\text { Wood + } \\
\text { Dung }\end{array}$ & Kutcha & Semikutcha & Outdoor & Indoor & $>15$ & $<15$ & $>6$ & $<6$ \\
\hline 1 & Budh & 4 & 9 & 4 & 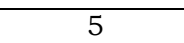 & 1 & 49 & 44 & 6 & 45 & 5 \\
\hline 2 & Waje & 42 & 8 & 49 & 1 & 1 & 4 & 45 & 5 & 32 & 18 \\
\hline & Total & 83 & 17 & 94 & 6 & 2 & 98 & 89 & 11 & 77 & 23 \\
\hline & Mean & 41.5 & 8.5 & 47 & 3 & 1 & 49 & 44.5 & 5.5 & 38.5 & 11.5 \\
\hline
\end{tabular}

Table No. 3- Data Of Spirometry Of Women In Budhgaon

\begin{tabular}{|c|c|c|c|c|c|c|}
\hline \multirow{2}{*}{ SR. NO. } & \multicolumn{3}{|c|}{ Control n= 50 } & \multicolumn{3}{c|}{ Subject n= 50 } \\
\cline { 2 - 7 } & FEV1\% & FVC\% & FEV1/ FVC\% & FEV1\% & FVC\% & FEV1/FVC\% \\
\hline Mean & 95.22 & 86.12 & 111.08 & 68.22 & 85.28 & 79.66 \\
\hline Var. & 178.09 & 111.91 & 198.73 & 317.17 & 34.88 & 371.49 \\
\hline Sqrt & 1.81 & 1.85 & 1.95 & & & \\
\hline Z & 14.93 & 0.45 & 16.09 & & & \\
\hline
\end{tabular}

Table No. 4- Data Of Spirometry Of Women in Wajegaon.

\begin{tabular}{|c|c|c|c|c|c|c|}
\hline & \multicolumn{3}{|c|}{ Control n = 50 } & \multicolumn{3}{c|}{ Subject n 50 } \\
\cline { 2 - 7 } SR. NO. & FEV1\% & FVC\% & FEV1/ FVC\% & FEV1\% & FVC\% & FEV1/FVC\% \\
\hline Mean & 95.02 & 88.58 & 107.46 & 71.50 & 88.46 & 79.16 \\
\hline Var. & 144.22 & 118.04 & 46.05 & 484.73 & 147.17 & 262.83 \\
\hline Sqrt & 1.82 & 1.88 & 1.93 & & & \\
\hline$Z$ & 12.89 & 0.06 & 14.65 & & & \\
\hline
\end{tabular}

Graph 1

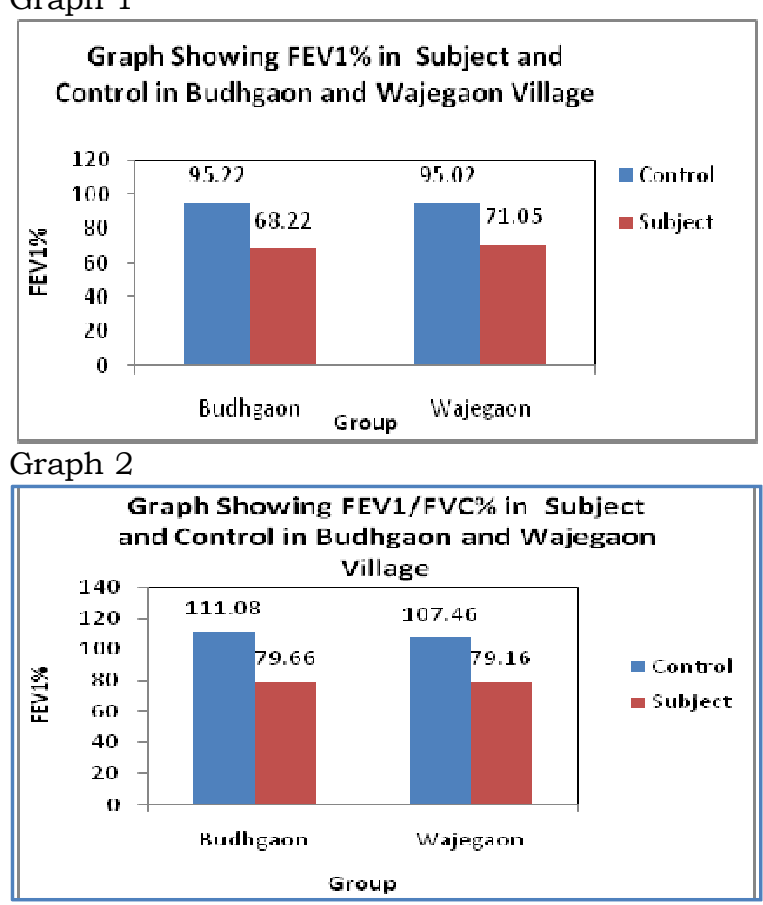

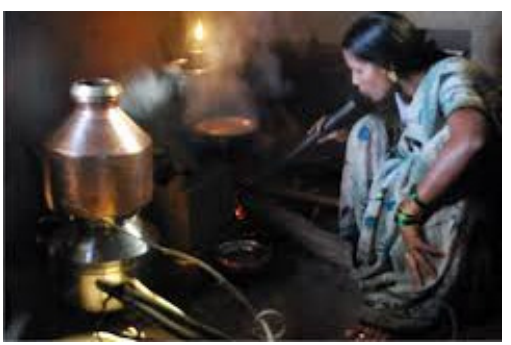

Figure 1. Women Using A Chulla

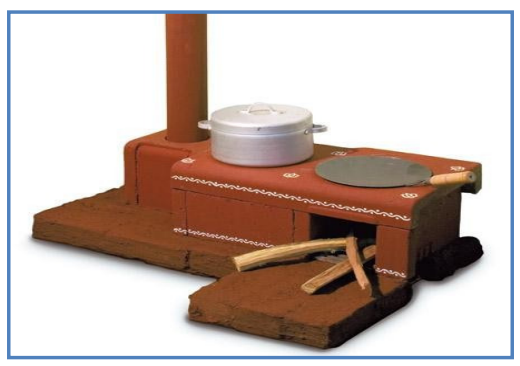

Figure 2. Image Of A Smokeless Chulla 


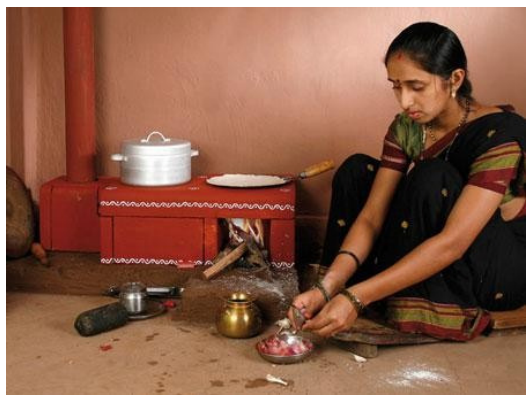

Figure 3. Women Using Smokeless Chulla

\section{Result and Discussion:}

From the above table no. 3 it is observed that the mean value of $\mathrm{FEV} 1 \%$ in control women is 95.22 , while the mean value of FEV1\% in experimental women is 68.22. The calculated $Z$ value of FEV $1 \%$ is 14.93 which is greater than table value 1.96 hence there is significant difference in FEV $1 \%$ of control and FEV1\% of experimental. The FEV1\% in expirmental women is less than $\mathrm{FEV} 1 \%$ of control women. If $\mathrm{FEV} 1 \%<80 \%$ then there is COPD. The result is significant at $5 \%$ level of significance.

The mean value of $\mathrm{FVC} 1 \%$ in control women is 86.12 , while the mean value of $\mathrm{FVC} 1 \%$ in experimental women is 85.28 The calculated $\mathrm{Z}$ value of $\mathrm{FVC} \%$ in 0.45 which is Less than table value 1.96 hence there is no significant difference in $\mathrm{FVC} 1 \%$ of control and $\mathrm{FVC} 1 \%$ of experimental. In COPD the value of $\mathrm{FVC} 1 \%$ $>80 \%$ or it may reduce in less amount. The value of $\mathrm{FVC} \%$ in experimental women is $>80$ hence there is COPD. The result is significant at $5 \%$ level of significance.

The mean value of $\mathrm{FEV} 1 / \mathrm{FVC} \%$ in control women is 111.08 , while the mean value of $\mathrm{FEV} 1 / \mathrm{FVC} \%$ in experimental women is 79.66. The calculated $Z$ value of $F E V 1 / F V C \%$ is 16.09 which is greater than table value 1.96 hence there significant difference in FEV1/FVC $\%$ of control and FEV1/ FVC\% of experimental. The $\mathrm{FEV} 1 \%$ and $\mathrm{FEV} 1 / \mathrm{FVC} \%$ in expirmental women is reduced than $80 \%$. If $\mathrm{FEV} 1 / \mathrm{FVC} \%<80 \%$ then there is COPD. The result is significant at $5 \%$ level of significance.

From the above table no. 4 it is observed that the mean value of $\mathrm{FEV} 1 \%$ in control women is 95.02 , while the mean value of $\mathrm{FEV} 1 \%$ in experimental women is 71.50 . The calculated $Z$ value of $F E V 1 \%$ is 12.89 which is greater than table value 1.96 hence there is significant difference in FEV1\% of control and FEV $1 \%$ of experimental. The FEV1\% in expirmental women is less than FEV $1 \%$ of control women. If $\mathrm{FEV} 1 \%<80 \%$ then there is
COPD. The result is significant at $5 \%$ level of significance.

The mean value of $\mathrm{FVC} 1 \%$ in control women is 88.58 , while the mean value of $\mathrm{FVC} 1 \%$ in experimental women is 88.46 The calculated $Z$ value of $\mathrm{FVC} \%$ in 0.06 which is Less than table value 1.96 hence there is no significant difference in $\mathrm{FVC} 1 \%$ of control and $\mathrm{FVC} 1 \%$ of experimental. In COPD the value of $\mathrm{FVC} 1 \%$ $>80 \%$ or it may reduce in less amount. The value of $\mathrm{FVC} \%$ in experimental women is $>80$ hence there is COPD. The result is significant at $5 \%$ level of significance.

The mean value of $\mathrm{FEV} 1 / \mathrm{FVC} \%$ in control women is 107.46 , while the mean value of $\mathrm{FEV} 1 / \mathrm{FVC} \%$ in experimental women is 79.16. The calculated $Z$ value of $\mathrm{FEV} 1 / \mathrm{FVC} \%$ is 14.65 which is greater than table value 1.96 hence there significant difference in FEV1/FVC\% of control and FEV1/ FVC\% of experimental. The $\mathrm{FEV} 1 \%$ and $\mathrm{FEV} 1 / \mathrm{FVC} \%$ in expirmental women is reduced than $80 \%$. If $\mathrm{FEV} 1 / \mathrm{FVC} \%<80 \%$ then there is COPD. The result is significant at $5 \%$ level of significance. $\mathrm{COPD}$ is diagnosed, if $\mathrm{FEV}_{1} \%$ is, $\mathrm{FEV}_{1} / \mathrm{FVC} \%$ ratio are $<80 \%$ then there is COPD.

The present study has demonstrated reduced COPD in women exposed to biomass fuel smoke in village Budhgaon and Wajegaon. Biomass fuel users were illiterate and from low socioeconomic status. In this study biomass fuel users had reduced lung function (FEV1\% < $80 \%)$ COPD when compared with LPG users. The concentration of particulate matter PM10 and PM2.5 in Indoor pollution during cooking was 3.4times higher in biomass using homes than LPG using households (WHO, 1992).

In present study total 200 women participated from village Budhgaon and Wajegaon out of which 100 women were exposed to biomass smoke (Budhgaon - 50 women and Wajegaon - 50 women) who were considered as subjects and 100 women were using LPG (Budhgaon - 50 women and Wajegaon - 50 women) who were considered as control group. Women from biomass group were illiterate and belonged to lower socio-economic status. In the LPG group most of the women were literate and belonged to middle class families. Lung function, forced expiratory volume in one second (FEV1) percent predicted (FEV1\%) in women exposed to biomass fuel smoke was significantly lower than women using LPG for cooking. In biomass fuel users, group in Budhgaon, out of 50 women, 26 women i.e. $52 \%$ women had reduced FEV $1 \%$ and 24 women i.e. $48 \%$ were normal. In village Wajegaon biomass fuel users 
group out of 50 women 22 women i.e $44 \%$ had reduced lung function and 28 women i.e $56 \%$ women were normal. Malik, S.K. (1984) from Chandigarh reported that exposure to fumes of biomass could result in impairment of ventilator function. Orozco, et al.; (2006) studied wood smoke exposure and risk of reduced FEV1\% predicted in Spain. In this study they found strong association between wood or charcoal smoke exposure and reduced FEV1\%. In the present study biomass fuel users in Budhgaon there were 50 women. Out of which 26 women had COPD (FEV1 \%< 80\%). In biomass fuel users in Wajegaon were 50 women. Out of which 22 women had COPD (FEV1\%<80\%). Like the present finding several investigators have reported reduction in lung function i.e. COPD in women chronically exposed to biomass smoke (Pandey 1984; Behera et al 1994).

In conclusion long term indoor exposure to wood smoke is a major risk factor for reduced FEV1\% (COPD) among women in village Budhgaon and Wajegaon in Sangli District.

\section{Conclusion:}

In conclusion long term indoor exposure to wood smoke is a major risk factor for Chronic Obstructive Pulmonary Disease. To prevent COPD due to biomass fuel smoke women can use clear fuel i.e. LPG or different kinds of smokeless chulla.

\section{References}

1. Behera, D., Jindal S.K. and Malhotra H.S. (1994): Ventilatory function in nonsmoking rural Indian women using different cooking fuels., Respiration (Herrlisheim), 61 : 89-92.

2. Bruce, N., Perez-Padilla R. and Albalak R. (2000): Indoor air pollution in developing countries: a major environmental and public health challenge., Bull World Health Organ, 78 : 1078-1092.

3. Smith, K., Desai M. and Mehta S. (2004) : Indoor smoke from solid fuels assessing the environmental burden of disease at national and local levels. Geneva, Switzerland, World Health organization.
4. IIPS - International Institute for Population Science. National family health survey $(\mathrm{MCH}$ and family planning), India 1992-93, International Institute for Population Science, Bombay 1995.

5. Malik, S. K (1994): Respiratory effects of effects of domestic cooking with particular reference to kerosene oil and liquefied petroleum gas. Bull PGI, $18: 4$.

6. Miller M.R, Hankinson J., Brusasco V., Burgos F., Casaburi R. and Coates A. (2005) : Series "ATS/ERS task force: Stadardisation of lung function testing" - Standardisation of spirometry. , Eur Respir J 2005; 26: 319-18.

7. Orozco, Levi, M., Garus Aymerich J., Villar J., Ramirez Sarmiento A., Anto J. N. and Gea J. (2006) : Wood smoke exposure and risk of chronic obstructive pulmonary disease, Eur Respir., J., 27: 542-546.

8. Pandey, M.R. (1984) : Domestic smoke pollution and chronic bronchitis in a rural community of the Hill region of Nepal., Thorax, 39:337-39.

9. Regalado, K., Perez-Padilla R., Sansores R., Ramirez JIP., Brauer M., Pare P. and Vedal S. (2006) : The effect of biomass burning on respiratory symptoms and lung function in rural Mexican women., Am J Respir Crit Care Med., 174: 901-905.

10. Rodolfo, J., Dennis Dario., Maldonaclo Sandra. and Norman (1996) : Wood smoke exposure and risk for obstructive Airways Diseases among women., Chest., 109 : 115-9.

11. Shengming, Liu., Yumin Zhou., Xiaoping Wang., Dali Wang., Jiachun Lu., Jingping Zheng., Nanshan Zhong, and Pixin Ran. (2007) : Biomass fuel are the probable risk factor for chronic obstructive pulmonary disease in rural south China., Thorax., 62(10): 889-897.

12. WHO, Geneva (1992) : Working paper from WHO Consultation - indoor air pollution from biomass fuel. 